\title{
Did the Czechs Want the Holocaust?

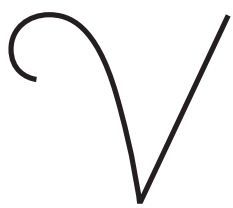 On a Modern History of the Jews in the Bohemian Lands ${ }^{1}$
}

\section{Ivo Cerman ${ }^{a}$}

a University of South Bohemia, Faculty of Arts, Institute of History ivo.cerman@email.cz

DOI 10.15240/tul/006/2021-1-013
The Holocaust and the history of the Jews should certainly have a place in the teaching of modern Czech history. However, teachers who reach for the book Prague and Beyond by an American-Czech-German team should be aware that it is not an entirely correct

piece of work. While early modern history is deplorably neglected here, their interpretation of the Holocaust tends to reinforce anti-Czech xenophobic prejudices. At the same time, this is a work that has been published with a massive promotional campaign. While we are reviewing here the German-language version, an English version entitled Prague and Beyond is already in publication, and the Czech and Hebrew versions are to follow. The book, which is to be "the first scientifically-based survey of the history of Jewish life in the Bohemian lands", received financial support from a number of institutions: the Collegium Carolinum, the German Federal Ministry for Culture and Media, the Czech Science Foundation, the Rothschild Foundation and the Fritz Thyssen Stiftung. ${ }^{2}$

1 ČAPKOVÁ, Kateřina \& KIEVAL, Hillel J. (eds.), 2020. Zwischen Prag und Nikolsburg. Jüdisches Leben in den böhmischen Ländern. Translated from English by Peter Groth. Göttingen: Vandenhoeck \& Ruprecht, 428 p. ISBN 978-3-525-36427-7; ČAPKOVÁ, Kateřina \& KIEVAL, Hillel J. (eds.), 2021. Prague and Beyond. Jews in the Bohemian Lands. Philadelphia: University of Pennsylvania Press, 384 p. ISBN 9780812253115.

2 We use data from the cover and the dedication of the book. The quotation is from an invitation to a book launch and from promotional material. Cf. https:// prag.diplo.de/cz-cs/themen/05-Wissenschaft_cz/3_Deu-CzeZusammenarbeit/ 
Based on the editorial reviews of the English version, it has been examined by three reviewers who are respected in their fields, but none of them specializes in Czech history. ${ }^{3}$ I am wondering whether they have been told about the errors revealed by experts from the Jewish Museum in Prague and other Czech historians (Cermanová, Baránek \& Putík, 2020, pp. 18-19; Cerman, 2020, pp. 725-750; Pešek, 2020, pp. 81-94). Given the reviewers' expertise in Polish history, I understand they may not be aware of the inadequacies of this book, but I do not see how one of them could argue: "The book should be greeted with enthusiasm not only by Czech historians and historians of modern European Jewry, but by European historians more generally and by other readers with an interest in the lost world of pre-Holocaust Europe." I can only hope that this review article will also be greeted with enthusiasm by readers who are not willing to be misled.

\section{Methodical Principles and Historiography}

According to the promotional text on the cover, the work claims to be characterized by innovative methodological procedures and a number of 'firsts'. It is to be the first work to portray the history of the Jews as "an integral and inseparable part of the history of Central Europe". It is meant to be the first work that will not be limited to Prague, but will consciously focus on the regions. The theoretical introduction by Kateřina Čapková and H. Kieval in the book (pp. 1-26) thus complements another methodological innovation: their interpretation

zwischen-prag-und-nikolsburg. The English version will bear the title Prague and Beyond. The History of the Jews in the Bohemian Lands. Philadelphia: Pennsylvania U.P. (to be published in 2020).

3 Promotional texts on the website of Pennsylvania University Press: Prague and Beyond. Jews in the Bohemian Lands. Edited by Kateřina Čapková and Hillel J. Kieval [online]. University of Pennsylvania Press [cit. 2021-06-18]. Available from: https://www.upenn.edu/pennpress/book/16264.html.

4 Promotional texts on the website of Pennsylvania University Press: Prague and Beyond. Jews in the Bohemian Lands. Edited by Kateřina Čapková and Hillel J. Kieval [online]. University of Pennsylvania Press [cit. 2021-06-18]. Available from: https://www.upenn.edu/pennpress/book/16264.html. 
is to consciously ignore the history of administration and focus instead on the cases of individual Jews (or "jüdische Erfahrung"). The editors believe that the use of sources from the provenance of the state administration was a major mistake in earlier Czech research, and allege that only more recent research rectified this shortcoming (p. 11). In the chapter on the First Republic, the joint authors added their voices to the charge that Czechoslovak historians of Jewish history allegedly focused solely on early modern times and economic history (p. 262).

However, the poetic list of new topics to be opened up to researchers when they leave the topic of state administration (p. 11) also shows that the editor, Kateřina Čapková, aims to exclude the state itself from this interpretation. Perhaps it could be admitted that this methodological dreaming is an attempt to allow interpretation from the point of view of actors, not from the point of view of external observers, but in a synthesis aimed at processing the history of a larger population, it is not applicable. One cannot simply build on subjective perspectives; it is also necessary to know how things were organized. Ignoring the history of the state, law and government can have drastic consequences, especially when authors aim to construct accusations of collective guilt. Fortunately, the chapters on earlier history did not follow the methodological guidelines from the Introduction at all, but unfortunately in the chapter on the Holocaust this principle has been followed with tragic consistency. To some extent, this also applies to Kateřina Čapková's own chapter on attitudes towards the Jews in the Czechoslovak (Socialist) Republic after 1945, where the role of the socialist state in the spread of anti-Zionism is gravely underestimated.

At the same time Čapková, as the editor, is of the opinion that it is new authors who have become interested in the "Jewish experience" who have joined forces to collaborate on this book. This may be true in the cases of $\mathrm{H}$. Kieval and Martina Niedhammer, but it can hardly be said of all the members of the author's team, as well as the works listed in the historiographical survey (p. 12). In the survey of innovative works, Čapková presents Michal Frankl's books on anti-Semitism (2007; 2011), which deal not with the history of the Jews but with anti-Semitism, and show us how Jews were regarded by their enemies. She also 
mentions Jan Láníček's bizarre work on the period of the Protectorate (2013; 2018), which also deals with the views of external observers, and lastly her own work on the Jews during the First Republic, which perceives Jews and the republic as antagonists (Čapková, 2005; 2012). To summarize, the works that Čapková mentions primarily follow the relationship of Jews with the majority of the population and describe it a priori as a conflict. It is certainly not possible to accept her claim that these works re-emphasize friendly "contact and association" ("Verflechtung und Verbindung”, p. 11).

On the other hand, this historiographical survey (pp. 6-12) ignores a number of more recent Czech works which actually try to trace the history of Jews rather than anti-Semitism, and noted "contact and association" in relation to the majority. There are, for example, a programmed work about the Hebrew censor Karel Fischer, a study of the history of Hebrew book printing, and one about the history of education. ${ }^{5}$ Even in regional historiography, which was frequently written under the influence of Hugo Gold's topographical lexicons of Jewish communities $(1929,1934)$, bilateral contact was often noted. The novelty of the period after the Velvet Revolution is rather the topic of anti-Semitism and pogroms, which is now no longer associated only with the German Nazis of the 20th century but also with earlier periods and the Czech majority ${ }^{6}$. With the rehabilitation of T. G. Masaryk

5 CERMANOVÁ, Iveta \& MAREK, Jindřich, 2007. Na rozhraní českého a židovského světa. Přiběh hebrejského cenzora a klementinského knihovníka Karla Fischera 1757-1844. Praha; PUTÍK, Alexandr (ed.), 2009. Cesta života. Rabi Jehuda Leva ben Becalel kol. 1525-1609. Praha; GANS, David, 2016. Ratolest Davidova. Praha (eds. ŠEDINOVÁ, Jiřina, SLÁDEK, Pavel \& BOUČEK, Daniel); SLÁDEK, Pavel (ed.), 2008. Malá encyklopedie rabinského judaismu. Praha; SLÁDEK, Pavel (ed.), 2019. Jehuda Leva ben Besal'el Maharal, Lampa přikázání / Ner micva. Praha; SIXTOVÁ, Olga (ed.), 2012. Hebrejský knihtiskv Čechách a na Moravě. Praha (English edition from 2012: Hebrew Printing in Bohemia and Moravia, Praha); the Sefer publishing House publishes Edice Judaika.

6 For example, VESELÁ-PRUDKOVÁ, Lenka, 2003. Židéa česká společnost v zrcadle literatury. Praha; PUTÍK, Alexandr, 1996. The Tumult of Mladá Boleslav (Jungbunzlau, Bumsla) in the Messianic Year 5426/1666. Judaica Bohemiae. Vol. 34, pp. 4-106. Cf.contributions in the journal Judaica Bohemiae and in the series of proceedings 
came a greater interest in Czech anti-Semitism during the Hilsner affair (Kovtun, 1994). However, research into the history of Jews had to cover several topics, and the Jewish Museum in Prague and its journal Judaica Bohemiae, whose post-1989 activities are not taken into account at all here, played a crucial role in maintaining a comprehensive focus.

Given the importance that editors attach to the Holocaust era, it is surprising that Miroslav Kárný's historical survey is not mentioned here at all. ${ }^{7}$ It is discussed only in Frommer's chapter on the Holocaust, with a manipulative commentary that suggests that Frommer is developing Kárný's initiatives (p. 268). In the post-1989 period, a number of studies of anti-Semitic agitation during the Second Republic were composed, the most impressive of which is the work of Jan Rataj (1997), and the Jewish Museum has also published a high-quality collection on Czech anti-Semitism in the post-war years (1945-1948) in which there are incisive and solid contributions by Jan Rataj, Radka Čermáková and Blanka Soukupová (Soukupová, Salner \& Ludvíková, 2009). Lastly, it is startling that in her survey Čapková does not mention the Czech historian Blanka Soukupová, who had already carried out systematic research on the topic that Čapková is working on here. This is the life of the Jews under socialism, of which Soukupová has actually produced a concise synthesis (2016). To a foreign public it appears that the "international team" is bravely opening up new taboo topics to the Czechs, although this is by no means the case.

In her introduction Čapková lays down interpretative principles (pp. 12-25), in which she applies the main theses to individual epochs of history from the 16th century to the present. In earlier history, these theses describe almost exclusively the activities of the state, but in the 20th century they view a kind of stateless majority population, i.e. the Czechs, as the only agent. She characterizes interwar

Židé a Morava (bibliography [online]: https://www.muzeum-km.cz; [cit. 202007-30]).

7 KÁRNÝ, Miroslav, 1991. „Konečné řešení.“ Genocida českých židů v německé protektorátní politice. Praha. Cf. MILOTOVÁ, Jaroslava, 2002. Miroslav Kárný (1919-2001). Terezinskéstudie a dokumenty, pp. 22-39. 
Czechoslovakia unilaterally as a "nation state", not as a republic (p. 4), and describes its democratic character as the product of Czechoslovak propaganda (p. 4). The evidence for this is an oft-quoted book by the American author Andrea Orzoff which is based on the Nazi work of propaganda Secret Funds of the Third Section $(1943)^{8}$. Unfortunately, Čapková did not verify the sources of this legend at all but repeated it uncritically.

In comparison with Kateřina Čapková's earlier work, there is a significant shift towards a negative image of interwar Czechoslovakia. Under the influence of the works of Ines Koeltzsch and Wolf Gruner, she emphasizes the importance of the Holešov pogrom of 1918 here, elevating its status to that of a defining event. However, it is not stated here that the perpetrators were brought to trial; the republic did not support such pogroms (p. 19) ${ }^{9}$. It is completely wrong to deduce anything about the character of the republic from this event. Contrary to the introductory arguments concerning friendly "contact and association", it is already clear in this introductory historiographical review that the main theme of the chapters on the 20th century is to be the hostility of the Czech majority towards the Jews.

\section{Early Modern History (up to 1918)}

After this introduction, there follow chapters on early modern history; it makes no sense to analyse the contents of these in detail. In conceptual terms, it should be noted that the chapters do not have the same thematic structure. In some there is a section on the legal context or on economics and geography, while in others there is not.

8 ORZOFF, Andrea, 2009. The Battle for the Castle. The Myth of Czechoslovakia in Europe. Oxford - New York, p. 69; URBAN, Rudolf, 1943. Tajné fondy III. sekce. Praha. In this work of Nazi propaganda, it is claimed that the positive image of Czechoslovak democracy was created by foreign Jewish journalists in return for generous bribes paid by the Ministry of Foreign Affairs. Orzoff copied the whole argument; she merely left out the allegation that Jews were responsible.

9 FIŠER, Zdeněk, 1996. Poslední pogrom. Kroměříž. Cf. KOELTZSCH, Ines, 2011. Antijüdische Straßengewalt und die semantische Konstruktion des ,Anderen' im Prag der Ersten Republik. Judaica Bohemiae. Vol. 46, No. 1, pp. 73-100; GRUNER, Wolf, 2016. Die Judenverfolgung im Protektorat Böhmen und Mähren. Göttingen, p. 24. 
The level of interpretation of earlier history is indicated by a notable mistake made by the editor Kateřina Čapková in her introductory theoretical theses. Here she mistakenly informs readers that in Bohemia Jews were expelled from royal cities in the 16th century (p.13). In reality, however, Jews in Bohemia were only forbidden to reside in mining towns (i.e. towns with mining rights) ${ }^{10}$, not in all royal towns. More interesting, however, is the source of this error. It is probably the popularizing work by Tomáš Pěkný ${ }^{11}$ which this "first scientifically-based historical survey" aims to replace. If we take a further look at the topic of cities, we will find that even in the chapter on the early modern period the authors Kasper-Marienberg and Teplitsky had not discovered the above-mentioned fact about mining towns (p. 36). H. Kieval repeats the same mistake in the chapter on the 19th century, where he speaks of the prohibition banning residence in royal cities (p. 121). In the chapter on the second half of the 19th century, there is a metaphysical interpretation of "Jewish spaces", which speaks of non-settlement in large cities and dispersal throughout the countryside, without distinguishing between Bohemia and Moravia (p. 164). None of the authors has made use of the recently-published editions of the censuses of the Jewish population by Ivana Ebelová (2002-2006; 2008).

In the chapter on the early modern period, the authors neglect such basic topics as accusations of ritual murder or the organization of Jewish communites, but pay disproportionate attention to the postWhite Mountain nobility, and in particular to Johannes Adolf von Schwarzenberg. The choice of this topic is incomprehensible, especially as the authors gradually progress towards a one-sided interpretation of the economic role of the Jews. They therefore make the same

10 DVORSKÝ, František (ed.), 1906. K historii Židů v Čechách, na Moravě a v Slezsku 906 až 1620. Sv. I, Praha, pp. 509-510, Document No. 713 (1568).

11 PĚKNÝ, Tomáš, 1993. Historie Židi̊ v Čechách a na Moravě. Praha, p. 60 and 394. However, even Pěkný's interpretation, which may be ambiguous and does not mention mining cities, does not claim that the expulsion of Jews "from royal cities” applied to Bohemia. The expulsion of 1454, ordered by Ladislav Pohrobek, applied to Moravia. 
mistakes of which their co-authors falsely accuse earlier Czechoslovak historiographers (p. 262). When Marienberg-Kasper and Teplitsky try to explain the specific case of the Jewish community in Česká Lípa, they rely on Gold's old lexicon of Jewish communities, which is, indeed, not an original approach (p. 44). However, the authors make a truly deplorable mistake in the passage on the messianic movement, where they focus their attention on the banner of the Messianist Shelom Molch (p. 63) ${ }^{12}$. In fact, however, they confuse it with a banner that was carried in Jewish processions in Prague.

The brief chapter on the 18th century, written by Michael L. Miller (pp. 84-111), begins well with an outline of state legislation. It does not follow the principles set out in the introduction, but this is only to its advantage. However, the core of the chapter, which the author compiles on the basis of the work of Pawel Maciejko (2015), focuses on the messianic movements of Shabatianism and Frankism. At the same time, there is a clear effort to foreground exotic moments (including alleged "orgies") and significantly overestimate the extent of these heresies in Bohemian and Moravian Judaism (pp. 99-101). However, in the next stage of interpretation, there is already too much about the state context, and there is a complete lack of any statement of interest in the "jüdische Erfahrung” of ordinary Jews. The Haskalah is given a deplorably brief treatment on two pages of the text (pp. 110-112). Under the influence of the author's interest in Moravia, the significant Prague Haskalah, including the Jeitteles family, is crammed into a brief introductory mention. The society of scholars around Baruch Jeitteles, and the activity of the Hebrew censor Karel Fischer in mediating between Jews and Christian scholars, are left ignored. Likewise, the importance of the Prague Tandlmarkt and the University Library as meeting places for the Christian and Jewish worlds in the period after the Josephine reforms is ignored. Nor is there anything about the life of rural communities.

12 The banner and robe are on display in the permanent exhibition of the Jewish Museum in the Maisel Synagogue in Prague. 
In the chapter on the pre-liberal period (1790-1860) by H. Kieval, attention is given to places of mutual encounter (pp. 120-121), but once again there is no explanation of the state context of Jewish life. Due to the faulty coordination of the chapters, any mention of the Jewish systemic patent of 1797, as well as the transformation of Jewish communities into Jewish religious communities after the Josephine reforms, has completely disappeared, so that the reader cannot gain any idea of long-term development. Here it should also be important to reconstruct the transitional period when the municipalities no longer had a Jewish judiciary system but still had some self-governing functions. After 1867, so-called political religious communities existed only in Moravia (Urbanitsch, 2018, pp. 39-64). The vast majority of the chapter is devoted to education and the university, followed by a brief passage on the events of the 1848 revolution. Only at the end is there a brief mention of the end of the Prague ghetto, and there is no mention of rural communities. Once again, this chapter fails to encompass the "jüdische Erfahrung".

The chapter on the liberal period (1860-1917) and the chapter on the period of the First Republic were compiled by a trio of authors (Michal Frankl, Ines Koeltzsch \& Martina Niedhammer). The chapter on the liberal period alone offers a comprehensive interpretation, paying balanced attention to the geography of settlement, the legal status of communities, reflections in literature, anti-Semitism and important Jewish personalities of the period. There is an interpretation of the law of 1890 which definitively regulated the status of Jewish religious communities. Even in the passage on anti-Semitism (pp.189-195), its author Michal Frankl follows Czech, German and Catholic anti-Semitism in a balanced way. In the following chapters, however, the last two types of anti-Semitism disappear without explanation. The authors focus on the legal status of "emancipated Jews" after 1867, but reduce it solely to freedom of movement, while the right to own land remains unmentioned.

However, given the serious accusations that occur in the next chapter about the First Republic, it should be noted that the author of this passage, Michal Frankl, does not assess the degree of Jewish 
freedom on the basis of contemporary civil and religious rights, but on the basis of a loosely constructed "discourse" in journalism. Nevertheless, since he is interested solely in anti-Semitic journalists, the outcome of such research is obvious in advance. It could be objected that in the period 1890-1914 not only journalists but also social scientists commented on the social situation from the Czech side. If any of these Czech scholars commented on nationalism in general terms ${ }^{13}$, the equality of citizens in the legal system ${ }^{14}$, or a non-conspiratorial interpretation of economic life (Tobolka, 1911), their conclusions were also applicable to the position of Jews, although they were not specifically mentioned ${ }^{15}$. In addition, there was the strong anti-religious movement of monism that highly honoured the Jew Baruch Spinoza (Krejčí, 1914, pp. 46-47). Secularization also occurred among Jews. In my opinion, 20 years ago it was sufficient to stick to the discussion of Czech anti-Semitism in journalism ${ }^{16}$ because it was a new topic, but today we can recognize that this debate is not about a biography of anti-Semitism. The point is to find out what views were current regarding the organization of the state and society, as otherwise it is not possible to draw general conclusions that society or the emerging state relied on a solution that excluded the Jews.

13 For example, CHALUPNÝ, Emanuel, 1905. Úvod do sociologie s ohledem na české poměry. Sv. II, Praha, Dodatek III, pp. 469-488.

14 For example, WEYR, František, 1908. Zum Problem eines einheitlichen Rechtssystems. Archiv für öffentliches Recht 23, pp. 529-580.

15 They were occasinally mentioned: for example, KREJČÍ, František, 1904. O filosofii prítomnosti. Praha, pp. 450-451; KREJČÍ, František, 1922. Positivní etika. Praha, pp. 388-392; CHALUPNÝ, Emanuel, 1908. Havlíček. Obraz psychologický a sociologický. Litomyšl, pp. 209-211; CHALUPNÝ, Emanuel, 1917. Sociologie. Díl V. Praha, p. 123. Despite their Jewish origins, the leading authorities for Czech scholars of this period were Georg Jellinek, Henri Bergson, and eventually Hans Kelsen.

Cf. FRANKL, Michal, 2001. The Background of the Hilsner Case. Political Antisemitism and Allegations of Ritual Murder 1896-1900. Judaica Bohemiae. Vol. 36, pp. 34-118. 


\section{Jews in the 'Nation State'}

In contemporary American historiography, the demise of the monarchy and the establishment of the republic are described as the transition from a multinational empire to a "nation state"17 (pp. 213-214), which increasingly oppressed minorities, including Jews, until in 1945 it reached its fully mature form with the creation of an "ethnically pure state". ${ }^{18}$ This perspective has also been adopted by the authors of the chapter on the First Republic (pp. 209-263). At the same time, it is obvious that at the level of factual reality both the Habsburg monarchy and the Czechoslovak Republic were multinational. At the normative level, though, the monarchy did not have a guaranteed multinational character, and the Czechoslovak Republic was not legally constructed as a "nation state", but as a republic with the priority of individual rights. Its basis was not the collective rights of nations but the rights of individuals. However, the chapter on the First Republic does not deal at all with the characteristics of the normative regulation of the status of Jews as citizens, nor with Judaism as a religion, but pronounces categorically condemnatory judgments on both.

Their first argument in support of an intolerant society is the fact that during the riots at the end of the war and the beginning of the republic there were also attacks on Jews, to which the authors attribute

17 On the idealization of the Habsburg monarchy in the USA, cf. JUDSON, Pieter, 2016. The Habsburg Empire: a New History. Cambridge, MA; MILLER-MELAMED, Paul, 2019. What the Habsburg Empire Got Right. The New York Times, 10. 9. 2019.

18 For example FROMMER, Benjamin, 2005. National Cleansing. Retribution against Nazi Collaborators in Postwar Czechoslovakia. Cambridge; ZAHRA, Tara, 2008. Kidnapped Souls. National Indifference and the Battle for Children in the Bohemian Lands 1900-1948. Ithaca, NY; ORZOFF, Andrea, 2009. The Battle for the Castle. Oxford New York; DEÁK, István, 2015. Europe on Trial. New York; FEINBERG, Melissa, 2017. Elusive Equality: Gender, Citizenship and the Limits of Democracy in Czechoslovakia 1918-1950. Cambridge; GERLACH, David W., 2017. The Economy of Ethnic Cleansing. The Transformation of German-Czech Borderlands after World War II. Cambridge; CONNELLY, John, 2020. From Peoples into Nations. A History of Eastern Europe. Princeton. Similarly in Europe HEIMANN, Mary, 2009. Czechoslovakia: The State that Failed. Cambridge; SCHMIDT, Victoria (ed.), 2019. The Politics of Disability in Interwar and Socialist Czechoslovakia. Segregating in the Name of the Nation. Amsterdam. 
a higher definitive meaning (pp. 214-218). At the same time, they describe these events as if Czech politicians and the public had been in control of the situation since 1917 and consciously "used violence as a substitute for expressing the principles according to which the national community would be organized in the future” (p. 215). They disregard the fact that in this climate of social unrest Czechs also stood against Czechs, and the city against the villages. The reader is left to believe that only attacks on Jews took place and anti-Semitism was the only driving force behind the violent mobs. However, the riots were also triggered by social problems, or - as in Holešov - by a desire for revenge for accusations allegedly made against a local citizen during the war. There are no interpretations of the character of the state in this chapter, and nothing about the "Soviet Republic" of Kladno or the communists. Instead, the riots are portrayed as a coordinated nationwide campaign to create a society that excluded Jews ${ }^{19}$. It is not stated here that such a community and such a state did not materialize. The civic status of women and Jews is thus construed on the basis of a discourse in the press about "loyalty" (pp. 218-230). This is similar to the procedure employed in the previous chapter.

The fact that Jews were guaranteed equality before the law and the right to vote is ignored in this chapter. This interpretation pays unilateral attention to the newly recognized identity of Jews as a nationality (p. 218, pp. 230-237) and ignores the traditional identity of Jews as followers of the Jewish religion. In this respect, they are following the one-sided interpretation of Kateřina Čapková (pp. 33-46, pp. 197-206). Although the authors ignore the republic's relationship to the Jewish religion, they make a categorical judgment: "Unlike other countries,

19 This distorted interpretation arose from the fact that Ines Koeltzsch, who was the first to emphasize the anti-Semitic character of these early disturbances, did not locate them within the actual context of place and time, i.e. within the context of the social unrest of 1918-1921, but within the theoretical concept of "exclusionary riots". With the help of this metaphysical span, she "proved" the exclusive character of the state which was in the process of emerging, without being interested in what this state was like. Cf. KOELTZSCH, Ines, 2011. Antijüdische Straßengewalt, p. 77. 
[Czechoslovakia] did not grant Jews even partial cultural autonomy" (p. 218). The horrifying nature of this sentence becomes clear when we realize that at that time these "other countries" also included Hitler's Germany, which actually imposed "cultural autonomy" on Jews in the Nuremberg Laws, as the goal of Nazi ideologues was to mark out assimilated Jews and to separate them as a nation from the Volksgemeinschaft (Forsthoff, 1933, pp. 38-42; Globke \& Stuckart, 1936, pp. 1-34). The Czechoslovak Republic did not in fact provide the Jews with this kind of cultural autonomy. On the other hand, Judaism was protected by law; just as under the Habsburg monarchy, Jewish religious communities were given the right to enforce claims by executive measures; they could associate in five unions of their choice, and in 1937 a uniform set of regulations was drawn up (Valeš, 2013, pp. 31-34). In religious education, the republic recognized Slovak cheders as private schools and, in addition, granted public rights to the famous Bratislava yeshiva, which provided for the religious education of future rabbis (Grünsfeld, 1932, pp. 22-25; Epstein, 1938, pp. 254-255). However, this fact is covered up in the book.

In conclusion (pp. 262-264), the authors describe the satisfaction of Jews with life in the Czechoslovak republic as "positive myths", which Jewish historians such as Hugo Gold allegedly created ex post facto in exile as a false memory of the glorious past. At the same time, it is once again surprising that the writers of these lines did not take into account the fact that Czechoslovak democracy of the interwar period was co-created and defended by Jewish legal scholars and publicists while they were still living in Czechoslovakia. We should mention Alfred Meissner, the (co)-creator of the Czechoslovak Constitutions of 1918 and 1920, Alfred Fuchs, the propagandist of Czechoslovak democracy, Franz Adler, the author of critical commentaries on constitutional law, and the social democrat Emil Strauss, the author of a "proCzechoslovak" history of the peasantry; we should also mention Arnošt Kraus, the historian of German literature in Bohemia... They were not dreamers; they knew what they were writing about, they co-created this state themselves, and, conscious of the risk, they defended their work against the German Nazis. Most of them paid for it with their lives. 
Now these historians are arguing that these were positive myths and that they need to be scientifically refuted. However, they consider the character of the interwar republic as a summary of the moral attitudes of its Czech inhabitants as individuals. Instead of monitoring whether religious tolerance was recognized and ensured in law, they speculate about whether individual residents were tolerant. They conclude that they were not. "As recent research has shown," they conclude, "neither religious nor ethnic tolerance [of the population] was the reason for the decline of anti-Semitism” (p. 263). The proof is once again a loosely constructed contemporary "discourse", this time about refugees, which is proved by reference to the work of the book's co-author Michal Frankl (p. 264). On the other hand, we should concede that in this chapter there is a very good passage on the organization of communities (pp. 237-250).

\section{"The Czech Holocaust"}

This shift in perspective is followed by a chapter on the Holocaust (pp. 267-318) written by the American historian Benjamin Frommer ${ }^{20}$. He also applies, to a much greater extent, the method of proof by means of individual examples, while the administrative framework of the German occupation is not described here even in its basic features. Foreign readers will not learn at all from his interpretation that even the regulations of the Protectorate government were valid only after approval by the German occupying power; they will not learn about the parallel German and Czech administrative systems, or about the double law, which differed for Germans and Czechs (Kárný, 1991, pp. 47-49; Maršálek, 1999; Maršálek, 2012, pp. 64-84). If Frommer states that the adoption of the Nuremberg definition of a Jew in the Property Act of 21 June 1939 allegedly "ended the efforts of the Czech authorities" (p. 280), and that "the Beran Cabinet" of March 1939 debarred Jews from a number of professions, it appears as if the Protectorate government itself initiated

20 He is preparing a book on this topic: The Ghetto without Walls: The Identification, Isolation, and Elimination of Bohemian and Moravian Jewry, 1938-1945. 
the decrees to separate Jews from society. He does not state (Kárný, 1991, pp. 29-34; Milotová, 2002, pp. 63-94; Petrkův, 2011, pp. 70-76) at all that the Protectorate government's proposal did not come into force. Nor does he claim that the "Czech definition" was milder than the Nuremberg Laws. At the same time, he makes a mistake because, being unaware of the double law, he does not realize that the Nuremberg regulations applied to "German" Jews immediately after the proclamation of the Protectorate. In the emotional description of the exclusion of children from Czech schools, which he describes as a Czech action (p. 291), he does not state that the Protectorate's Minister of Education tried to preserve compulsory school attendance for Jewish children (Kasperová, 2010, pp. 50-70).

The result is an approach to scholarship that allows the author to attribute the main initiative to the Czech population without having to bother explaining how this could be possible in the conditions of the occupying administration. Frommer replaces the missing administrative context with a narrative about the growing hostility of the Czech population towards Jews which continued to increase until it culminated in the Holocaust. It is this narrative that gives his interpretation the semblance of coherence.

Frommer's interpretation is designed as if the autonomy of the Protectorate was genuine, and the Czechs, together with the Germans, became Aryan lords over the local Jewry. ${ }^{21}$ The anti-Jewish measures are described as being introduced by the occupying power solely under pressure arising from Czech street riots and the "local authorities". It is as if he were repeating Wolf Gruner's notion that the Holocaust was enforced by means of Czech "local initiatives". ${ }^{22}$ With this turn,

21 He describes the Czechs as Aryans on p. 293, 304. What was more important was who possessed citizenship of the Reich according to the Nuremberg Laws. Frommer does not even take into account the inferior racial classification of Czech forced labourers. In his opinion of the Czech Aryans, he actually agrees with the Czech Nazi sympathizer Lukáš Beer. Cf. BEER, Lukáš, 2014. Hitlerovi Češi. Brno.

22 GRUNER, Wolf, 2016. Die Judenverfolgung, pp. 7-22, 138-270. The book was published in an English translation, The Holocaust in Bohemia and Moravia. Czech Initiatives, German Policies, Jewish Reponses. New York - Oxford, 2019, and in Czech, 
Gruner bypasses the fact that during the Protectorate, self-government, i.e. elected councils, which included municipalities, districts and "lands" during the First Republic, ceased to exist. Not only did the local authorities not reflect the will of the people even in the administration of their own affairs but they could no longer initiate decisions by the supreme authorities "from below".

Frommer's thesis of bottom-up initiatives is based not on new discoveries about local government but on manipulative stylistics. Frommer consciously uses terms such as "Czech government", "local authorities", and "Czech leaders" (p. 272) to evoke a semblance of real autonomy and continuity with the First Republic. For example, in his interpretation of the Beran government's anti-Jewish measures of 17 March 1939, after the occupation, he claims that these were only a "sharpening of measures" initiated by the "Czechoslovak government" (pp. 275-276); in the burning of synagogues and the demolition of Jewish buildings, Frommer suggests a semblance of continuity with the republic by speaking of the period "before the occupation" (pp. 288-289), followed by an interpretation of the demolition of these objects during the occupation. ${ }^{23}$ Here, too, details taken out of context come to his aid; in this case there are repeated reports that this or that city paid for the demolition or for the land, which once again creates the impression that the cities themselves initiated these actions from anti-Jewish motives.

He also creates continuity and generality by tagging the agents behind anti-Jewish street riots during the Second Republic and the early years of the Protectorate with general designations such as "Czech fascists", "radicals", "local authorities" or even "tschechische

Pronásledování Židův Protektorátu Čechy a Morava: místní iniciativy, centrální rozhodnutí, reakce Židi̊, Praha, 2019. Cf. the review by Vojtěch Blodig (Judaica Bohemiae. 2017, Vol. 52, No. 2, pp. 141-152).

23 He takes the data about demolished synagogues from Jakub Machala's article from 2014 'Unbearable Jewish Houses of Prayer. The Nazi Destruction of Synagogues Based on Examples from Central Moravia'.Judaica Bohemiae. Vol. 44, No. 1, pp. 59-88. 
Faschistenbanden" (p. 275). In reality, however, the cases he mentions are those of the Vlajka (Flag) and Národní tábor fašistický (Fascist National Camp). However, Frommer does not deliberately give concrete details to provide a semblance of universality. He specifically mentions Vlajka only in connection with the attack on the empty Jewish cemetery chapel in Pilsen of 6 March 1939 (p. 274). ${ }^{24}$ This case is deliberately chosen to support the appearance of general anti-Jewish riots even before the German occupation. However, Frommer does not state that Vlajka was already a banned organization during the Second Republic, as early as 11 November 1938 (Rataj, 1997, p. 36). The "Czech" police intervened against its demonstrations during the Second Republic, even in the first years of the Protectorate. Frommer deliberately gives the impression that the street actions of Vlajka members and fascists during the Second Republic and the occupation were a kind of expression of the prevailing Czech position, and that they had the support of "leading Czech circles" (p. 272). Frommer does not take into account that Vlajka never had the support of the government, the Národní obec fašistická disintegrated at the beginning of the occupation, and the popularity of Vlajka members and fascists in Czech society weakened. They never managed to form a mass organization. ${ }^{25}$

The second significant event to illustrate pressure by the Czechs is the attacks on Jews in Brno in the summer of 1939. This is also Frommer's only attempt to reconstruct the mechanism that was supposed to lead from local initiatives to anti-Jewish measures (pp. 281-282). Frommer sets the demonstration in the context of "pressure from both German and Czech authorities on district officials to impose further restrictions [on Jews]", but does not say that these were in fact demonstrations by the Národní tábor fašistický. This was a series of demonstrations that had more to do with power struggles within fascist organizations, and the Protectorate police always intervened to oppose them. Frommer, however, seizes on the famous attack on the Café Esplanade

24 Cf. ŠPIRKOVÁ, Věra, 2000. Židovská komunita v Plzni. Domažlice, p. 78.

25 Cf. PASÁK, Tomáš, 1999. Český fašismus 1922-1945 a kolaborace 1939-1945. Praha. 
of 15 August 1939, during which the police were unable to intervene because members of the SA and SS also took part in it (Pasák, 1998, pp. 127-128; Konečný, 2013, pp. 42-43). According to Frommer, this was a march by a crowd of 800 "Czech fascists and Germans" in the centre of Brno during which they allegedly beat 14 Jews and caused the death of Paul Drexler. In reality, it was the act of a fascist faction that did not have the support of the Protectorate government, but in Frommer's vague presentation it has the air of one of the ubiquitous rampages by Czechs yearning for a decree separating Jews and Czechs in public spaces. The result was indeed the issuing of such an order by the Protectorate Minister of the Interior. Frommer is apparently referring to the decree on relations between the Aryan and non-Aryan populations of 3 August $1939 .{ }^{26}$ However, it is obvious that the pro-German Minister of the Interior Josef Ježek, who issued it, was cooperating with the Germans of his own free will, not out of fear of a handful of Brno demonstrators. Moreover, even this regulation could not come into force without the approval of the German occupying authorities.

Using similar methods, Frommer approaches the portrayal of the relationship between Czechs and Jews, which he describes as one of escalating hostility and oppression, which, surprisingly, intensified even during the occupation. At the same time, Frommer conceals Czech expressions of solidarity with Jews from 1939-1941. He also describes this period as one of growing hostility (pp. 271-272 and 275, 280-283, 299-300).

As evidence, he uses quotations from the memories of survivors, from which he chooses only carefully selected items. Looking at the original, we find that he has completely distorted the meaning of the original account.

26 PASÁK, Tomáš, 1998. Pod ochranou, p. 128. The assumption about „local initiatives" was copied by Frommer from an article by GRUNER, Wolf. Protektorát Čechy a Morava a protižidovská politika v letech 1939-1941. Terezinské studie a dokumenty. 2005, pp. 25-58, here: p. 34; similarly PETRŮV, Helena, 2011. Zákonné bezpráví, pp. 89-91 (in agreement with Gruner). 
Drawing on Heda Kaufmannová's memoirs, he proves the "explosive hostility and anti-Semitism" of the Czechs "immediately after Munich” (pp. 271-72 and 273). Although Kaufmannová describes the bitter experience of her dismissal from the Institute for Social Medicine at Charles University, she also adds her own reflections on Czech anti-Semitism, which by no means confirm Frommer's suggestions. She describes the decent behaviour of her Czech colleagues and, when asked by her Jewish friends how the Czechs were treating her now, replies: "Well, just the same as before, and even better; they helped us in our troubles as much as they could. But I'll have more to say about them another time” (Slavíček, 1999, p. 28).

Dagmar Lieblová's memories are supposed to be another testimony to the ubiquitous hostility of the Czechs. An unknown perpetrator was said to have stuck a poster on her father's office door with the words “Jewish doctor - life-threatening” (p. 272). Dagmar Lieblová does in fact mention this incident, but gives in addition an overall picture of the situation which is once again completely different. "In Kutná Hora, though, our family did not encounter strong anti-Semitism, apart from a few publications and provocations” (Lauermann, 2013, p. 34).

As for help given by Czechs to Jews, Frommer cites only the case of "one official" who was arrested because "he was a friend of the Jews" (p. 299). In his submission, this seems to be an exception to Czech behaviour. However, he does not fail to provide an example of Czech cruelty by narrating a bizarre attempt by a group of pro-German Czech fascists to exploit the situation after the German invasion of 15-16 March 1939 and occupy the small border town of Ivančice. As Frommer says without supplying any context, a certain Otto Ehrlich in Ivančice committed suicide "in response to an attempt by local Czech fascists to take control of the town" (p. 275). Frommer does not even consider whether the fact of the German occupation itself played a part in this. In addition, a few days later, a factory owner, Friedrich Placzek, committed suicide in the same small town because he was being bullied by his own German employees. The regional historian Silvestr Novaček cites both cases in his book about Ivančice during the Occupation, but Frommer chooses to highlight only one of them (Nováček, 1984, p. 24, 26). This 
raises the question: why did the American historian emphasize the one that was related to a bizarre action by Czech fascists which had no further impact? The case of Placzek was cited by Frommer without mentioning his name, and was downplayed as a "quarrel with German employees" (p. 275). If the historian had really wished to understand how the Holocaust was organised in this small town, he would have had to discuss the local informant Heinrich Ottava and the local German community (Nováček, 1984, pp. 29-35).

The intention to portray the Czechs as co-oppressors compels Frommer not to mention situations where German repression affected Czechs and Jews mutually. He applied such a method in describing the repression in Kladno after the "murder of a German officer" (p. 279). His submission involves unilateral measures against the Jews, when in fact, after the assassination of the German constable Wilhelm Kniest in June 1939, civil martial law was declared throughout the whole of Kladno. The mayor of Kladno, František Pavel, also fell victim to this (Hrošová \& Šebelová, 2005, pp. 33-49; Vykouk, 2013, pp. 103-110).

The preparatory phase of the Holocaust was the exclusion of Jews from public life, which Miroslav Kárný aptly likened to a "ghetto without walls" (Kárný, 1991, p. 50). To this Frommer adds a description of several cases in which Jews were concentrated in certain places before the establishment of Terezín. These places were known to Czechoslovak historiography from the 1960 s onwards ${ }^{27}$, but it is true that Kárný did not include them in his synthesis. However, Frommer describes the origin of these assembly points as concessions to the Czechs, whose will in this case was to be expressed by the "local authorities" and cities.

Frommer focuses on three alleged ghettos that originated before Terezín (p. 287). First of all, there was the castle of Mladá Boleslav, where Jews were concentrated as early as $1940^{28}$; then there is Třešt

27 BUBENÍČKOVÁ, Růžena, KUBÁTOVÁ, Ludmila \& MALÁ, Irena, 1969. Tábory utrpení a smrti. Praha, pp. 135-167. Nowadays lists of assembly points are also available online, e.g. the project see online [cit. 2020-07-30]. Available at: https://zapom-nicky.pamatnik-terezin.cz/.

28 Cf. CERMAN, Ivo et al., 2018. Středni Čechy 1918-2018. Prưvodce historií. Praha, p. 154. 
in the Vysočina region, to which Jews from Jihlava were evicted ${ }^{29}$, and finally Uherský Brod, to which Jews from the "Zlín region” were to be evicted. In all three cases, Frommer states that the ghetto was created on the orders of the Oberlandrat, but frames everything with an explanation of the exclusion of Jews from public life, which he describes as if only to retroactively confirm and unify measures that were said to have been taken in Czech cities by the free will of the Czechs (pp. 281-282).

He describes the establishment of the ghetto in Mladá Boleslav as a concession to Czech cities, which were now said to understand that they had permission to get rid of the Jews (p. 287). Later on, the "local authorities" in Mladá Boleslav and Uherský Brod were reportedly upset that the transports had been delayed and that they had to live with the Jews longer than other cities (p. 308). In the case of the ghetto at Mladá Boleslav Castle, though, Frommer does not say that the Jews were taken there to make their flats available to the Germans. Moreover, the Jews continued to have to pay rent for them... ${ }^{30}$ This definitely constituted a step favouring the Germans and ordered by the German authorities. Without an explanation of the existence of a dual administration, however, the foreign reader will not even understand that the Oberlandrats were part of the higher German administrative system.

The operation of transports and the mass murder of Czech Jews in the years 1941-1945 (pp. 297-318) are also described by Frommer as activities that happened with at least the vigorous assent of the Czech population. In describing an early attempt to transport Jews from Ostrava to Nisko in 1939 (p. 300), Frommer even conceals the fact that Czech protests were taking place (Kárný, 1991, p. 44). Only in the case of transports from Prague does he admit that they were "perceived as disturbing”, but only because the Czechs were afraid for themselves. They saw here "an ominous sign of what might later be in store for the Czech majority” (p. 304). Frommer does not take into account

29 Cf. VÍTKOVÁ, Romana, 2009. Židé na Dačicku. Prague. Diploma Thesis, Faculty of education, Charles University.

30 Report by Otto Seidler [online]. Recorded on 22 June 2016, accessed on 26 July 2020. Available at: https://www.pametnaroda.cz/cs/seidler-otto-1930. 
that the Czech public spoke out against Nazism and Nazi anti-Semitism even before the occupation, at a time when free discussion was still possible. ${ }^{31}$ Even the ageing president T. G. Masaryk took the trouble to write a refutation of Hitler's Mein Kampf (Masaryk, 1935).

For the organization of transports from the regions (pp. 302-306), Frommer makes banal general statements that "Jews travelled by train, bus, horse-drawn carriage, or on foot from villages and towns” (p. 303) to "central locations" (p.306). He continues to adhere to the principle of ignoring the history of administration. Surprisingly, the role of the Czechs is also forgotten in his interpretation of the end of the war in Terezín. Frommer emphasizes that the camp, in which spotted typhus was spreading, was handed over to the "administration" of the Red Cross (p. 318), but does not say that the Czech physician Karel Raška provided medical care on behalf of this organization, nor that at in those days the inmate Alfred Meissner, a former (co)-author of the Czechoslovak constitution, was an important member of the local government. $^{32}$ There is nothing about the Czech relief event for Terezín, nor about the self-help care for child survivors which was organized by Přemysl Pitter (Lajsková, 2015; Cerman, 2018, p. 184).

31 In chronological order, e.g. KOZÁK, Jan B., 1932. 'Národ jako úkol'. In: Tři přednášky o nacionalismu. Praha, pp. 48-76; FISCHER, Josef Ludvík, 1932. Třetí řišse. Úvodem do současného politického stavu. Brno, pp. 13-17; KŮRKA, Václav, 1932. Hitler a hitlerismus. Brno; FUCHS, Alfréd, 1933. Hitlerovská hesla a jejich ideologický podklad. Moderní stát. Vol. 6, pp. 326-328, BAUER, František, 1933. Hitlerova třetí ř́še a náš stát. Praha; MEISNER, Josef, 1934. Rasismus hrozí kultuře. Praha; WEIGNER, Karel et al., 1934. Rovnocennost evropských plemen a cesty k jejich zušlechtování. Praha; RÁDL, Emanuel, 1935. O německé revoluci. Praha; CHALUPNÝ, Emanuel, 1935. Povaha evropských národů, zvláště Němců. Praha; RÁDL, Emanuel, 1935. Zur politischen Ideologie der Sudetendeutschen. Praha; MODRÁČEK, František, 1935. Politické a mravní ideje rasového nacionalismu. Praha; BAUER, František, 1936. Můj boj: Hitler o sobě a svých dilech. Praha (2nd edition 1937); MODRÁČEK, František, 1937. Fašistické prevraty. Praha, pp. 24-28, 40, 82-93; FISCHER, Josef et al., 1937. Jejich boj. Praha; KOZÁK, Jan B., 1938. Věda a duch. Praha; Homo Ferus [SUK, Vojtěch], 1938. Divoši ve střední Evropě. Mýthus rasistů o nás. Praha.

32 BENEŠOVÁ, Miroslava, 1990. Situace v Terezíně po skončení války. Terezínské listy. Vol. 18, pp. 7-31; SOUKUPOVÁ, Blanka, 2016. Židé, pp. 32-36 (a reprint of the report by František Fuchs about the situation in Terezín). 


\section{In Socialist Czechoslovakia}

If we relinquish the idea of innate Czech anti-Semitism, only the communist period brought a longer era in which anti-Semitic accusations became part of the ideology disseminated by our Czechoslovak government. This period alone signified long-term manipulation of the population by the media in the spirit of anti-Semitic prejudices. However, the main theme of this state anti-Semitism was its attitude towards the state of Israel, which also reflected the traditional accusations against Jews of greed, world domination, the killing of children and, more recently, imitation of the Nazi Third Reich. The importance of the foreign policy issue was all the greater because only a small fraction of the Jewish population was left. ${ }^{33}$ Many of the survivors migrated to Israel.

However, Kateřina Čapková does not monitor the socialist state's long-term attitude towards Israel in her chapter on the period from 1945 to the present (pp. 320-375) ${ }^{34}$. The author aims primarily to refute the notion of the Czechs' friendship with the emerging state of Israel (pp. 337-338). It is said to be merely a narrative which dissolves after a "more thorough analysis of documents", which shows that the main motive of the government in enabling migration was to get rid of Jewish refugees from Poland who were passing through Czechoslovak territory. Another motive was said to be the desire of President Edvard Beneš to create a pure "nation state" (pp. 329, 339). Following the bizarre work by Jan Láníček, Čapková constructs a parallel with the expulsion of the Germans (p. 339). She explains military support for Israel only in terms of attempts to get rid of alleged overproduction by the arms industry and a surplus of looted weapons (p. 339). ${ }^{35}$ These revelations

33 Cf. LENDVAI, Paul, 1971. Anti-Semitism without Jews. Communist Eastern Europe. New York.

34 This chapter is the result of GAČR Grant project 16-01775Y, 'Začlenění židovského obyvatelstva do poválečného Československa a Polska', which Kateřina Čapková and her colleagues have been working on since 2016.

35 Here Čapková refers to two articles by Edvard Beneš in Foreign Affairs 23, 1944, No. 1, pp. 35-47; 24, 1946, No. 3, pp. 397-410. In the first article, however, Beneš does not say that only Czechs and Slovaks will be allowed to live in the state, but politely speaks of the hope that the future state will be "home to Czechs, Slovaks 
are followed by a brief acknowledgment of ideological motives within hostility towards Israel (p. 340), bringing the subject to a close. Of the Arab-Israeli wars, Čapková mentions only the Six-Day War, but solely in connection with the negotiations of the IV. Congress of Writers and the cancellation of celebrations marking a thousand years of Jewish presence in Bohemia (p. 362). The chapter is written in such a way that it significantly underplays the importance of communist ideology and the socialist state in spreading anti-Semitic accusations that lasted until 1989. As in Frommer's chapter, there is a lack of basic information about the context that would allow the reader to construct an overview. The reader is manipulated into accepting the idea that anti-Semitism proceeded naturally from the local population.

For this reason, a disproportionately long passage is devoted to the short period from 1945-1948, i.e. before the Communist takeover of 1948 (pp. 320-341). The author introduces the feelings of three survivors on the basis of three interviews (pp. 321-322), followed by an explanation of the difficulties experienced by German-speaking Jews who decided to save themselves from an intolerant environment by leaving for Germany (pp. 329-332). The author claims that the Czechs were indifferent to the suffering of the Jews because the Jews were not mentioned by name in the Great Retribution Decree (p. 333), forgetting to mention that crimes against the Jews formed a separate chapter in the Czechoslovak documents for the Nuremberg trial. ${ }^{36}$ As there is no clear explanation of restitutions and communist influence, readers are left to believe that intolerant Czechs were collectively responsible for all the wrongs, and that President Beneš was especially to blame as the

and Carpathians" and states that pre-war conditions cannot be restored. There is nothing about ethnic purity here. In the second, he dreams of a Central European federation and notes the ongoing deportation, saying that it will be better to have a "nation state" inside, without Germans and Hungarians. He mentions Jews as victims of the Nazis who need to be compensated (p. 408). There is nothing about the expulsion of the Jews. This is probably the result of uncritical acceptance of quotations from the book by LÁNÍČEK, Jan. Czechs, pp. 47-53. 
main driver (pp. 329-339). They will not learn about the legal basis for restitutions prepared by the government in exile in London, or about the early ideological resistance of communists to restitution of large amounts of property to "capitalists", or about anti-Jewish speeches by the Communist Minister of Information Václav Kopecký, the Communist Interior Minister Václav Nosek and Julius Ďuriš, the Communist Minister for Agriculture. ${ }^{37}$ They do not learn about the objective problems caused by German measures (killing of the original owners, the unacceptable Nuremberg definition of a Jew, removing transport numbers from objects) or the Soviet confiscation of gold and factory equipment as spoils of war. They do not know about the ideological background to the dispute over the Varnsdorf textile factory, in which the court gave a verdict in favour of the Jewish claimant for restitution, but the unions prevented the restitution by striking. The reader does not learn that the Czech legal experts criticized the practice of restitution (Krčmár. 1946, pp. 257-261), and that the Communist Interior Minister Nosek was nevertheless forced to issue a decree in September 1946 recognizing that Jews were victims of Nazism, and another decree excluding German-speaking Jews from expulsion (Kuklík et al., 2015, p. 176).

Čapková does not talk about these wrongs in a factual way, but with an emphasis on details, such as the statement that the migrants were transported in "cattle wagons". At the same time, she fails to mention the Communist interior minister Nosek, and instead calls the "Czechoslovak government" or "Czechoslovakia" as a whole the culprit (p. 339). In this interpretation, Czech nationalism is to blame, and the reader will not learn that the consent of part of the non-Communist public to nationalization did not proceed from nationalism but from the conclusions that citizens drew about mistakes made by the interwar republican democracy. Instead of this, she explains these injustices,

37 Cf. KUKLÍK, Jan et al., 2015. Jak odškodnit holokaust? Problematika vyvlastnění židovského majetku, jeho restituce a odškodnění. Praha, pp. 135-194. 
among other things, by the conflict between "transnationally involved" Jews and "acutely nationalist Czech/Czechoslovak society" (p. 336).

This is followed by the Slánský trial, where the author focuses on describing idealistic motives that allegedly led Jews, including Slánský, to join the Communist Party (pp. 341-342). She justifies this by their alleged desire to escape oppression and prevent the return of Nazism, although all the main defendants belonged to the Communist Party before the war (Slánský and Geminder even since the 1920s). The trial allegedly took these idealists by surprise. If we take into account Slánský's role in the forced collectivization of agriculture, church trials and other repressions, this argument sounds very unconvincing indeed. ${ }^{38}$ On the other hand, in giving motives for the trial, Čapková conceals accusations of cooperation by the alleged conspirators with Israel, which is, however, important for an understanding of the aims of the trial. ${ }^{39}$ The Party needed this trial to explain its sudden change in policy towards Israel and domestic economic failures, aided by an old stereotype of Jews who were said to work treacherously in public office for their own good and for that of Israel. The trial also blamed the alleged conspirators for aiming to take control of the Varnsdorf textile factory, about which Čapková says nothing at all in the book. ${ }^{40}$ Čapková ignores the propaganda machinery and instead claims that anti-Semitic demonstrations by the public arose naturally from a basis of Czech anti-Semitism; this was not a "Soviet import", as evidenced by StB reports on the behaviour of the population and the experiences of two German Communists (p. 343). ${ }^{41}$ We should add that Čapková claims at the outset that post-war anti-Semitism had domestic roots

38 JECH, Karel, 2001. Soumrak selského stavu 1945-1960. Praha, p. 38; KAPLAN, Karel, 1993. Nekrvavá revoluce. Praha, pp. 73-75, 294; VEBER, Václav, 2014. Třetíodboj. ČSR $v$ letech 1948-1953. Pardubice (passim).

39 Proces s vedením protistátního spikleneckého centra v čele s Rudolfem Slánským, 1953. Praha, p. 26, 30, 67, 77, 117 and elsewhere.

40 Ibid., p. 30.

41 The individuals concerned were Louis Fürnberg and C. F. Wieskopf. In this Čapková uncritically paraphrases a book by GERBER, Jan, 2017. Ein Prozess in Prag. Das Volk gegen Rudolf Slánský und Genossen. Göttingen. 
(“... es handelte sich um hausegemachte Vorurteile”, p. 24). In other words, she suggests that the Czechs held innate anti-Semitic views independently of state propaganda.

She remains faithful to this thesis in the following interpretation, where she simultaneously ignores all the phases of anti-Zionist state propaganda and at the same time suggests, based on a reductive reading of the work of the Czech-Canadian sociologist Alena Heitlinger, that Czechs behaved anti-Semitically of their own accord and that thanks to their expressions of hatred, the object of discrimination allegedly realized his Jewish identity (p. 353) ${ }^{42}$ Reading such literary clichés, one cannot rid oneself of the impression that Čapková is endeavouring to conform to stereotypes about Eastern Europe.

Such an interpretation relieves the Communist Party and committed journalists of any responsibility for spreading anti-Semitism. Moreover, the way in which Čapková understands this topic raises suspicions that she was probably not familiar with the real arguments of Communist propaganda at all. ${ }^{43}$ In the first phase from 1952 to 1967/1968, when older economic accusations were combined with charges of serving international imperialism, Communist propaganda was not limited to a one-sided positive pretence that the Czechs did not discriminate against Jews in "our" country, as Čapková claims. (p. 340). I consider it important to state that the Minister of Information Václav Kopecký, who does not figure in her book at all (!), was capable of claiming on the one hand that anti-Semitism existed only in the West, but at the same time of publicly refusing to return property to Jewish "capitalists"; he was threatening Jews with investigation

42 HEITLINGER, Alena, 2006. In the Shadows of the Holocaust and Communism. Czech and Slovak Jews since 1945. New Brunswick - London (Czech edition from 2007: Ve stínu holokaustu a komunismu. Čeští a slovenští Židé po roce 1945, Praha). Cf. SOUKUPOVÁ, Blanka, 2009. 'Modely životních osudů českých Židů po šoa'. In: SOUKUPOVÁ, Blanka, SALNER, Peter \& LUDVÍKOVÁ, Miroslava (eds.). Židovská menšina. Praha, pp. 81-91.

43 The texts of anti-Zionism were made available as part of the ÚSTR's materials for teaching in schools as early as 2018. Available at: http://antisemitismus4589.de-jepis21.cz/kapitola/uvod/ [cit. 2020-07-28]. 
of their activities during the war, while simultaneously expressing sympathy with the Jewish victims of the Holocaust. ${ }^{44}$

We must distinguish from this the second, racist phase from 1967 to 1989 , which was current at the time of normalization, when propaganda began to portray Israelis as successors to the Nazis who considered themselves a superior race, viewed the Arabs as inferior, and waged wars because they were innately bloodthirsty. The foundations of this approach had already been laid by the Communist journalist Ladislav Mňačko when he was sent in 1961 to report on the trial of Eichmann (Mňačko, 1961, pp. 189-212). In her book Čapková only mentions Mňáčko’s pro-Israel speeches from 1967-68, which, however, came only after a turnaround caused by the Six-Day War (p. 362).

For incomprehensible reasons, she is silent about the Communist attempt to interpret the Prague Spring as a conspiracy organized by Israel, led by Eduard Goldstücker, which again leads to an apology for the Communist state. ${ }^{45}$ Nor does she mention the demonstration by Czech Jews in support of Israel on 1 May 1968 which is not widely known. ${ }^{46}$ Such "gaps" in interpretation should be described as serious shortcomings because these expressions of support for the Jews and Israel are at odds with the image of popular "spontaneous"

44 In a book published in 1945, Kopecký promised that property would not be returned to wealthy Jews, adding that "Every citizen of Jewish descent will be treated as strictly as he behaved nationally in the past and [...], strict investigations will also be carried out into how he treated his own Jewish fellow believers during the Second Republic, during the German occupation”. KOPECKÝ, Václav, 1945. Antisemitismus poslední zbraní nacismu. Praha, p. 15; other speeches from 1951-1952 in KAPLAN, Karel \& BULÍNOVÁ, Marie (eds.), 1993. Československo a Izrael 1945-1956, dokumenty. Praha.

45 JEVSEJEV, Jevgenij, 1970. Doslov. In: IVANOV, Jurij. Sionismus. Praha, pp. 154-189; Poučeníz krizového vývoje ve straně a společnosti po XIII. Sjezdu KSČ, 1971. Praha, p.19; BOHATKA, Jiří, 1972. Sionismus bez masky. Tribuna, 8. 3. 1972. Cf. LENDVAI, Paul, 1971. Anti-Semitism. New York, pp. 260-300; SOUKUPOVÁ, Blanka, 2016. Židé. Bratislava, pp. 213-230.

46 Thanks to Martin Borges, a participant in this event, for drawing my attention to it. It is documented in footage that was used in the Soviet propaganda report on 1968 (in the possession of the author). 
rhetoric, the Egyptian-Israeli peace, based on the Camp David agreement of 1978, was deprecated. This propaganda created artificial parallels with Czech history, especially with the Lidice massacre. At the time of normalization, Deir Jassin was characterized as the Palestinian Lidice (Mádr, 1973;1982, p. 17), and during the war in Lebanon in 1982, the Israeli army was accused of killing civilians in the Sabra and Shatila camps, which was caused by Lebanese phalanxes. The term "occupation" was used consistently, which was supposed to support the association between Israel and the Nazis. The last major event before the fall of the regime was the 1987-1989 intifada. The images created in these campaigns are with us to this day. None of this work by the socialist media, nor the work of left-wing intellectuals, is mentioned in the book.

The image of Charter 77, too, is somewhat idealized here. The fact is concealed that even dissent has not been able to free itself from the effects of anti-Zionist propaganda; thus the author describes the Chartists as unequivocal friends of Judaism (pp. 367-368). She cites a document about Jewish monuments of 5 May 1989, signed by the right-wing Sasha Vondra and two other speakers ${ }^{50}$, but does not mention Petr Uhl's far-left wing anti-Israeli focus ${ }^{51}$, nor the anti-Israeli articles in the independent newspaper Lidové noviny, which supported the intifada ${ }^{52}$. The result is a simplified picture of Czech reality that suits the stereotypical ideas of Western readers.

The account of the internal life of Jewish communities displays an uncritical judgment about the politics of the socialist state. The claim that these communities experienced unusual prosperity in the $1950 \mathrm{~s}$ (p. 345) is scarcely credible, given that this was the period of the

50 Prohlášeni 28/89, 5. IV. 1989. In: PREČAN, Vilém (ed.), 1990. Charta 77. Od morální $k$ demokratické revoluci. Scheinfeld-Schwarzenberg - Bratislava, pp. 349-370.

51 UHL, Petr et al., 1982. Program společenské samosprávy. Köln, p. 225. After the Velvet Revolution Uhl signed the anti-Semitic petition Dopis Palestincü Havlovi (A Letter from the Palestinians to Havel) of September 2010, which was directed against Václav Havel.

52 For example, [-mp-], 1988. Bezvýchodný blízký východ?. Lidové noviny, May 1988, p. 13; [-ir-], 1988. Palestina: stát bez území. Lidové noviny, December 1988, p. 15. 
anti-Semitism which Čapková describes here. The foreign reader probably does not know and will not understand that the Czechs saw the fate of Israel as a parallel to the fate of Czechoslovakia at the time of Munich. It is my opinion that the sympathy of the Czechs for Israel is also proved by František Kolár's ideological pamphlet "Zionism and Anti-Semitism", which was composed after the Prague Spring in order to eradicate these sympathies. ${ }^{47}$ It even contains printed letters from Rudé Právo readers expressing support for Israel as a parallel to Munich (Kollár, 1970, pp. 83-84). We should add that this author was also capable of fighting against anti-Semitism and showing pity for the victims of the Holocaust (Idem). During the 1970s and 1980s, a number of journalists spoke out against Israel (Milan Mádr, Milan Jelínek, Josef Skydánek, Jiří Bohatka, Alexej Pludek, Josef Šebesta), and television and newspaper reports were written in the same spirit.

From these journalistic texts, about which Čapková remains silent, we can see that anti-Zionist arguments did not originate spontaneously "from the people", but were created and disseminated by Communist journalists and politically engaged intellectuals. Soon this was joined by visual journalism produced by Czechoslovak television. ${ }^{48}$ This propaganda drew its content from the Arab-Israeli conflict. On the one hand, Palestinian terrorism was covered up; on the other hand, Israeli reactions were portrayed as gratuitous violence. On the one hand, terror at the 1972 Olympics in Munich was depicted in relative terms; on the other hand, the Israeli army was criticized for the Yom Kippur War of 1973 , which was portrayed as aggression. ${ }^{49}$ Despite its peaceful

47 KOLÁR, František J., 1970. Sionismus a antisemitismus. Praha; NOVÁK, Jan, 1970. Židovská otázka u nás neexistuje. Pravda, 27. 7. - 28. 7. On Kolár, see SOUKUPOVÁ, Židé, pp. 242-250.

48 On the ÚSTR website (http://antisemitismus4589.dejepis21.cz/) we have published excerpts from two films from the ČT archives as part of the teaching material (Pravá tvár sionismu, late 1960s, author unknown; Obyčejnýsionismus, c. 1982, author unknown).

49 For example, BOHATKA, Jiří \& DOLEJŠ, Svatopluk, 1973. Světový sionismus a mír na Středním východě. Rudé Právo, 22. 8.; MÁDR, Milan, 1973. Viník se jmenuje Izrael. Rudé Právo, 20. 10.; MÁDR, Milan, 1973. Výchova k nadřazenosti. Rudé Právo, 20. 10. 
extinction of rural Jewish communities which had no members. In the era of socialism, the author surprisingly focuses on pious Jews, namely refugees from Carpathian Ruthenia. She touches on the conflict between them and the religiously lukewarm Czech Jews, but in its presentation this looks like a narrative about the difficult coexistence of refugees with intolerant Czech society. We should add that Blanka Soukupová, whose well-substantiated studies are not even cited here, has already explored this same topic (Soukupová, p. 204). While in Blanka Soukupová's work the life of communities under socialism is embedded within a systematic interpretation of organization, church politics, the internal life of communities and memory, in Čapková's work we find a formless accumulation of data about cultural and religious life, selected to support the image of an intolerant Czech society. Nor will we discover anything about the popularity of Ota Pavel's short stories here.

Even in the period after the Velvet Revolution, Čapková does not continuously monitor the relationship with Israel, and she no longer attempts to establish periodic milestones in Jewish life. She does not mention the new migration to Israel which took place after the borders were opened because she could hardly interpret it as an effort by the government to create an "ethnically pure space". Neither the more friendly attitude of the Czech government towards Israel nor the initiatives of Václav Havel in this field are listed here. Instead, Čapková devotes attention to the 2004 internal conflict within the leadership of the Prague Jewish religious community, whose cultural significance is somewhat overestimated.

On the other hand, she pays no attention to the fundamental change in the cultural climate in the Czech Republic which occurred after Israel's war with Hezbollah in 2006. I believe that this return to anti-Zionism was linked to a parallel positive reassessment of socialism which manifested itself in particular in attacks on the Institute for the Study of Totalitarian Regimes and the rejection of any criticism of socialism as "unscientific". The novel feature was that the arguments of Communist anti-Zionism now merged with the anti-Israeli arguments 
of the Western left, which were based on criticism of colonialism. ${ }^{53}$ This cultural shift was brought about by left-wing intellectuals, newspapers and public television, not by ordinary people. Few of us historians and scholars within the humanities confronted it.

The final chapter on demography provides an encyclopaedic list of individual Jewish communities (pp. 377-410). It is based on quality research on this topic which co-author Lenka Matušíková has been carrying out for a considerable time.

\section{Conclusion}

In conclusion, it can be stated that this book is certainly not an instance of a "scientifically-based survey of the history of Jews in the Bohemian lands". Due to poor coordination, there are large gaps that make such an overview impossible. The chapters on the 20th century thus bear the stamp of fabricated propaganda. Its aim is to portray the Czechs as representatives of an innate anti-Semitism who deliberately created an ethnically pure state. A side-effect of this argument is the deplorable dishonouring of the democratic era of the First Republic (1918-1938). This interpretation is not new; it is an imitation of the style in which the country is written about in the USA, and it is not even based on new sources, but merely on manipulative stylistics. It addresses xenophobic stereotypes about the people of Eastern Europe. In an honest approach, the empirical historian should try to establish concrete facts and generalize only if it is possible to explain how a larger collective might be involved in technical terms (i.e. the use of the media, state coordination, legislation, etc.). In this work, we encounter more of an unsuccessful attempt to generalize on the basis of speculations about the nature of majority thinking even prior to 1945 , when public

53 The political scientist Pavel Barša in particular contributed to the new legitimization of anti-Zionism, following Communist propaganda and at the same time imitating the American Norman Finkelstein. Cf. BARŠA, Pavel, 2006. 'Doslov - humanistické židectví proti kultu Holocaustu'. In: FINKELSTEIN, Norman, 2006. Průmysl Holocaustu. Praha, pp. 107-126; idem, 2011. Pamět a genocida. Úvahy o politice holocaustu. Praha. 
opinion was not yet being scientifically determined in our country. The alleged anti-Semitic outlook of the whole nation is then proved with the help of questionable sources (e.g. quotations from memoirs, "discourses" about concepts, and StB reports). For the community of historians, this book is a warning against the impending return of propaganda to historiography.

\section{Literature}

BARŠA, Pavel, 2006. Doslov - humanistické židovství proti kultu Holocaustu. In: FINKELSTEIN, Norman. Průmysl Holocaustu. Praha: Dokořán, pp. 107-126. ISBN 80-7363-068-0.

BARŠA, Pavel, 2011. Pamět a genocida. Úvahy o politice holocaustu. Praha: Argo. ISBN 978-80-257-0368-7.

BENEŠOVÁ, Miroslava, 1990. Situace v Terezíně po skončení války. Terezínské listy. No. 18, pp. 7-31.

BOHATKA, Jiří, 1972. Sionismus bez masky. Tribuna, 8. 3. 1972.

BUBENÍČKOVÁ, Rưžena, KUBÁTOVÁ, Ludmila \& MALÁ, Irena, 1969. Tábory utrpení a smrti. Praha: Svoboda.

ČAPKOVÁ, Kateřina \& KIEVAL, Hillel J. (eds.), 2020. Zwischen Prag und Nikolsburg. Jüdisches Leben in den böhmischen Ländern. Translated from English by Peter Groth. Göttingen: Vandenhoeck \& Ruprecht. ISBN 978-3-525-36427-7.

ČAPKOVÁ, Kateřina \& KIEVAL, Hillel J. (eds.), 2021. Prague and Beyond. Jews in the Bohemian Lands. Philadelphia: University of Pennsylvania Press. ISBN 9780812253115.

ČAPKOVÁ, Kateřina, 2005. Češi, Němci, Židé? Národní identita Židů v Čechách 1918-1938. Praha-Litomyšl: Paseka. ISBN 80-7185-695-9. (English edition from 2012: Czechs, Germans, Jews? National Identity and the Jews of Bohemia. New YorkOxford: Berghahn Books. ISBN 978-0-85745-474-4.).

CERMAN, Ivo et al., 2018. Střední Čechy 1918-2018. Prưvodce historií. Praha: Nakladatelství Lidové noviny. ISBN 978-80-7422-661-8.

CERMAN, Ivo, 2020. Nad knihou o Židech a českém nacionalismu. Český časopis historický. Vol. 118, No. 3, pp. 725-750. ISSN 0862-6111.

CERMANOVÁ, Iveta, BARÁNEK, Dan \& PUTÍK, Alexandr, 2020. Židé mezi Prahou a Mikulovem. Pokus o souhrnné zpracování Židů v českých zemích. Roš Chodeš. No. 4, pp. 18-19. ISSN 1210-7468.

Československo a norimberský proces. Hlavni dokumenty norimberského procesu o zločinech nacistů proti Československu, 1946. Praha: Ministerstvo informací. 
DVORSKÝ, František (ed.), 1906. K historii Židů v Čechách, na Moravě a v Slezsku 906 až 1620. Sv. I. Praha: Bohumil Bondy.

EBELOVÁ, Ivana (ed.), 2008. Soupis židovských familiantů v Čechách z roku 1783. Praha: Národní archiv. ISBN 978-80-86712-53-6.

EBELOVÁ, Ivana et al., 2002-2006. Soupis židovských rodin v Čechách z roku 1793, I-VI. Praha: Národní archiv. ISBN 80-85475-91-X.

EPSTEIN, Oskar, 1938. Židovské školství v ČSR. In: CHLUP, Otakar et al. Pedagogická encyklopedie. Sv. I. Praha: Novina, pp. 254-255.

FIŠER, Zdeněk, 1996. Poslední pogrom. Kojetín: KATOS. ISBN 80-85945-06-1.

FORSTHOFF, Ernst, 1933. Der totale Staat. Hamburg: Hanseatische Verlagsanstadt.

FRANKL, Michal, 2001. The Background of the Hilsner Case. Political Antisemitism and Allegations of Ritual Murder 1896-1900. Judaica Bohemiae. Vol. 36, pp. 34-118. ISSN 0022-5738.

FRANKL, Michal, 2007. Emancipace od Židů. Český antisemitismus na konci 19. století. Praha-Litomyšl: Paseka. ISBN 978-80-7185-882-9. (German edition from 2011: „Prag ist nunmehr antisemitisch“. Tschechischer Antisemitismus am Ende des 19. Jahrhunderts. Berlin: Metropol. ISBN 978-3-86331-019-6.).

GLOBKE, Hans \& STUCKART, Wilhelm, 1936. Kommentare zur deutschen Rassengesetzgebung. München-Berlin.

GOLD, Hugo, 1929. Die Juden und Judengemeinden Mährens in Vergangenheit und Gegenwart. Brno: Jüdischer Buch- und Kunstverlag.

GOLD, Hugo, 1934. Die Juden und Judengemeinden Böhmens in Vergangenheit und Gegenwart. Praha: Jüdischer Buch- und Kunstverlag.

GRUNER, Wolf, 2016. Die Judenverfolgung im Protektorat Böhmen und Mähren. Göttingen: Wallstein. ISBN 978-3-8353-1910-3.

GRÜNSFELD, Josef, 1932. Nové dějiny ješivy. In: GOLD, Hugo (ed.). Židovská náboženská obec v Bratislave v minulosti a súčasnosti. Bratislava: Marenčin PT, pp. 22-25.

HEITLINGER, Alena, 2006. In the Shadows of the Holocaust and Communism. Czech and Slovak Jews since 1945. New Brunswick - London: Transaction Publishers. ISBN 0-7658-0331-3. (Czech edition from 2007: Ve stínu holokaustu a komunismu. Čeští a slovenští Židé po roce 1945. Praha: G plus G, ISBN 978-80-86103-97-6).

HROŠOVÁ, Marie \& ŠEBELOVÁ, Olga, 2005. Kladenská trestní akce 1939. Slánský obzor. Vol. 113, pp. 33-49. ISSN 1214-3847.

JECH, Karel, 2001. Soumrak selského stavu 1945-1960. Praha: Ústav pro soudobé dějiny Akademie věd ČR. ISBN 80-7285-010-5. 
JEVSEJEV, Jevgenij, 1970. Doslov. In: IVANOV, Jurij. Sionismus. Praha: Svoboda, pp. 154-189.

KAPLAN, Karel \& BULÍNOVÁ, Marie (eds.), 1933. Československo a Izrael 1945-1956, dokumenty. Praha.

KAPLAN, Karel, 1993. Nekrvavá revoluce. Praha: Mladá Fronta.

KÁRNÝ, Miroslav, 1991. „Konečné řešeni.“ “ Genocida českých židů v německé protektorátní politice. Praha: Academia.

KASPEROVÁ, Dana, 2010. Výchova a vzdělání židovských dětív protektorátu a v ghettu Terezín. Praha: Nakladatel Filozofická fakulta UK v Praze.

ISBN 978-80-7308-327-4.

KAUFMANNOVÁ, Heda \& SLAVÍČEK, Antonín (ed.), 1999. Léta 1938-1945. Válečné vzpominky. Praha: Ústav pro soudobé dějiny AV ČR. ISBN 80-85270-85-4.

KOELTZSCH, Ines, 2011. Antijüdische Straßengewalt und die semantische Konstruktion des ,Anderen' im Prag der Ersten Republik. Judaica Bohemiae. Vol. 46, No. 1, pp. 73-100. ISSN 0022-5738.

KOLÁR, František J., 1970. Sionismus a antisemitismus. Praha: Svoboda.

KOLÁR, František, 1970. Antisemitismus a sionismus. Rudé Právo, 9. 4. 1970.

KONEČNÝ, Michal, 2013. Brno nacistické. Brno: Host. ISBN 978-80-7294-956-4.

KOPECKÝ, Václav, 1945. Antisemitismus poslední zbraní nacismu. Praha: Svoboda.

KOVTUN, Jiří, 1994. Tajuplná vražda. Př́ípad Leopolda Hilsnera. Praha: Sefer. ISBN 80-900895-9-3.

KRČMÁ̌̌, Jan, 1946. Poznámky k dekretu prezidenta republiky ze dne 19. 5. 1945, č. 5/45 a k zákonu ze dne 16. 5. 1946 čís. 128/46. Právník, pp. 257-261.

KREJČÍ, František V., 1914. Světový názor náboženský a moderní. Dle přednášek pořádaných Svazem socialistických monistů. Praha: Ústřední dělnické knihkupectví.

KUKLÍK, Jan a kol., 2015. Jak odškodnit holokaust? Problematika vyvlastnění židovského majetku, jeho restituce a odškodnění. Praha: Univerzita Karlova v Praze, nakladatelství Karolinum. ISBN 978-80-246-2798-4.

LAJSKOVÁ, Lenka (ed.), 2015. Přemysl Pitter: „Nečekejme velké chvíle.“Akce zámky (1945-1947) v zrcadle korespondence let 1946-1990. Praha: NPMK. ISBN 978-80-86935-31-7.

LÁNÍČEK, Jan, 2013. Czechs, Slovaks and the Jews, 1938-48. Beyond Idealisation and Condemnation. Basingstoke, New York: Palgrave Macmillan UK. ISBN 978-0-230-36874-3 (Czech edition from 2018: Ve stínu šoa. Československá exilová vláda a Židé během druhé světové války a po ní. Praha: Academia. ISBN 978-80-200-2733-7). 
LAUERMANN, Marek (ed.), 2013. Přepsali se-takjsem tady. Přiběh Dagmar Lieblové. Brno: Společnost pro jazyky. ISBN 978-80-906295-0-9.

LENDVAI, Paul, 1971. Anti-Semitism without Jews. Communist Eastern Europe. New York: Doubleday.

MACIEJKO, Pawel, 2015. The Mixed Multitude. Jacob Frank and the Frankist Movement 1755-1816. Philadelphia: University of Pennsylvania Press. ISBN 9780812223439.

MÁDR, Milan, 1973. Deir Jassin - palestinské Lidice. Rudé Právo, 20 October 1973. MÁDR, Milan, 1982. Stopami tragédie. Praha: Rudé právo.

MARŠÁLEK, Pavel, 1999. Veřejná správa Protektorátu Čechy a Morava v letech 1939-1945. Praha: Vodnář. ISBN 80-85889-26-9.

MARŠÁLEK, Pavel, 2012. Pod ochranou hákového kř́že. Nacistický okupační režim $v$ českých zemích 1939-1945. Praha: Auditorium. ISBN 978-80-87284-20-9.

MASARYK, Tomáš G., 1935. Hitlers Credo. Prager Presse, 30 April 1935.

MILOTOVÁ, Jaroslava, 2002. K historii Neurathova nařízení o židovském majetku. Terezínské studie a dokumenty. Praha: Academia. ISBN 80-200-1031-9.

MŇAČKO, Ladislav, 1961. Já, Adolf Eichmann. Praha: Státní nakladatelství politické literatury.

NOVÁČEK, Silvestr, 1984. Nacistické „konečné řešeni“ “židovské otázky v Ivančicích. Brno: Okresní muzeum Brno-venkov.

NOVÁK, Jan, 1970. Židovská otázka u nás neexistuje. Pravda, 27.-28. July.

ORZOFF, Andrea, 2009. The Battle for the Castle. The Myth of Czechoslovakia in Europe. Oxford - New York: Oxford University Press. ISBN 978-0-19-536781-2.

PASÁK, Tomáš, 1998. Pod ochranou řišse. Praha: Práh. ISBN 80-85809-88-5.

PASÁK, Tomáš, 1999. Český fašismus 1922-1945 a kolaborace 1939-1945. Praha: Práh. ISBN 80-7252-017-2.

PĚKNÝ, Tomáš, 1993. Historie Židů v Čechách a na Moravě. Praha: Sefer. ISBN 80-900895-4-2.

PEŠEK, Jiří, 2020. Judaica Bohemiae. Vol. 55, No. 2, pp. 81-94. ISSN 0022-5738.

PETRŮV, Helena, 2011. Zákonné bezpráví. Židév Protektorátu Čechy a Morava. Praha: Auditorium. ISBN 978-80-87284-19-3.

Poučení z krizového vývoje ve straně a společnosti po XIII. Sjezdu KSČ, 1971. Praha: ÚV KSČ.

Prague and Beyond. Jews in the Bohemian Lands. Edited by Kateřina Čapková and Hillel J. Kieval [online]. University of Pennsylvania Press [cit. 2021-06-18]. Available from: https://www.upenn.edu/pennpress/book/16264.html. 
Prohlášení 28/89, 5. IV. 1989. In: PREČAN, Vilém (ed.), 1990. Charta 77. Od morální $k$ demokratické revoluci. Scheinfeld-Schwarzenberg: Československé středisko nezávislé literatury - Bratislava: ARCHA, pp. 349-370.

RATAJ, Jan, 1997. O autoritativní národní stát. Ideologické proměny české politiky v druhé republice 1938-1939. Praha: Karolinum. ISBN 80-7184-516-7.

Report by Otto Seidler [online]. Recorded on 22 June 2016, accessed on 26 July 2020. Available at: https://www.pametnaroda.cz/cs/seidler-otto-1930.

SOUKUPOVÁ, Blanka, 2016. Židév českých zemích po šoa. Identita poraněné paměti. Bratislava: Marenčin PT. ISBN 978-80-8114-842-2.

SOUKUPOVÁ, Blanka, 2009. ,Modely životních osudů českých Židů po šoa'. In: SOUKUPOVÁ, Blanka, SALNER, Peter \& LUDVÍKOVÁ, Miroslava (eds.). Židovská menšina v Československu po druhé světové válce. Od osvobození k nové totalitě. Praha: Židovské muzeum, pp. 81-91. ISBN 978-80-86889-90-0.

SOUKUPOVÁ, Blanka, SALNER, Peter \& LUDVÍKOVÁ, Miroslava (eds.), 2009. Židovská menšina $v$ Československu po druhé světové válce. Od osvobození k nové totalitě. Praha: Židovské muzeum. ISBN 978-80-86889-90-0.

ŠPIRKOVÁ, Věra, 2000. Židovská komunita v Plzni. Domažlice: Nakladatelství Českého lesa. ISBN 80-86125-14-9.

TOBOLKA, Zdeněk V. (ed.), 1911. Česká politika. Dil 4: Moderní stát a jeho úkoly. Praha: Jan Laichter.

UHL, Petr et al., 1982. Program společenské samosprávy. Köln: Index e. V.

URBAN, Rudolf, 1943. Tajné fondy III. sekce. Praha: Orbis.

URBANITSCH, Peter, 2018. Die politischen Israelitengemeinden in Mahren. Entstehung und legistische Grundlagen, ihre politische Rolle im Nationalitätenstreit, Trennung ihrer säkularen und religiösen Aufgabenbereiche. Judaica Bohemiae. Vol. 53, No. 1, pp. 39-64. ISSN 0022-5738.

VALEŠ, Václav, 2013. Právní úprava postavení církví a náboženských společnostív období první československé republiky 1918-1938. Praha: V. Valeš. ISBN 978-80-260-3707-1.

VEBER, Václav, 2014. Třetí odboj. ČSR v letech 1948-1953. Pardubice: Univerzita Pardubice. ISBN 978-80-7395-786-5.

VÍTKOVÁ, Romana, 2009. Židé na Dačicku. Prague. Diploma Thesis, Faculty of Education, Charles University.

VYKOUK, Jaroslav, 2013. Hnědý mrak nad Kladnem. Kladno: Halda. ISBN 978-80-905223-4-3. 